\title{
Impact of COVID-19 in Individuals with Autism Spectrum Disorders: Analysis of a National Private Claims
}

\section{Insurance Database}

Arun Karpur, MD, MPH

Vijay Vasudevan, $\mathrm{PhD}$

Andy Shih, $\mathrm{PhD}$

Thomas Frazier, PhD

Autism Speaks, 1060 State Rd, Princeton, NJ

Author note:

AK conceptualized the study, supervised data analysis, wrote the manuscript, TF conceptualized and contributed to the writing, VV contributed to the writing of manuscript, and AS helped with conceptualization of the study. Authors also acknowledge contributions from FAIR Health Inc., specifically Ali Russo, Eric Okurowski, David Cheng, and Josh Smolinsky.

Arun Karpur is the Director, Data Science and Evaluation Research, Autism Speaks at Princeton NJ office. Correspondence regarding this paper should be directed to Arun Karpur at arun.karpur@autismspeaks.org. No external funding was received for this research. 


\section{Author note}

AK conceptualized the study, supervised data analysis, wrote the manuscript, TF conceptualized and contributed to the writing, VV contributed to the writing of manuscript, and AS helped with conceptualization of the study.

Authors also acknowledge contributions from FAIR Health Inc., specifically Ali Russo, Eric Okurowski, David Cheng, and Josh Smolinsky.

Arun Karpur is the Director, Data Science and Evaluation Research, Autism Speaks at Princeton NJ office.

Correspondence regarding this paper should be directed to Arun Karpur at arun.karpur@autismspeaks.org. No external funding was received for this research. 


\begin{abstract}
The COVID-19 pandemic continues to have a detrimental impact on individuals with disabilities. Data from FAIR Health’s FH® NPIC (National Private Insurance Claims) database, ${ }^{1}$ one of the nation's largest databases of private insurance claim records, were analyzed to understand the experiences of individuals with ASD in COVID-19 pandemic. Multivariate logistic regression models revealed that individuals with ASD + ID were nine times more likely to be hospitalized $(\mathrm{OR}=9.3 ; 95 \% \mathrm{CI}: 6.9-12.5)$ and were nearly six times more likely have an elevated length of hospital stay $(\mathrm{OR}=5.9 ; 95 \% \mathrm{CI}: 3.5-10.1)$ compared those without ASD + ID. These findings point to their need for prioritization in access to vaccines for preventing COVID-19 infection and morbidities.
\end{abstract}

Key Words: Autism Spectrum Disorders, COVID-19 Pandemic, Hospitalization, Intellectual Disabilities, FAIR Health Inc., 
medRxiv preprint doi: https://doi.org/10.1101/2021.03.31.21254434; this version posted April 5, 2021. The copyright holder for this preprint

(which was not certified by peer review) is the author/funder, who has granted medRxiv a license to display the preprint in perpetuity.

It is made available under a CC-BY-NC-ND 4.0 International license .

\section{Impact of COVID-19 in Individuals with Autism Spectrum Disorders: Analysis of a National Private Claims \\ Insurance Database}

The global pandemic from SARS-CoV-2 virus infection causing the Coronavirus disease in 2019 (COVID19) has led to wide ranging crises in health and social supports for vulnerable individuals, especially for those with developmental disabilities and autism spectrum disorders (ASD). A study of individuals with ASD in Germany illustrated that the COVID-19 pandemic increased ASD-related behavioral difficulties, reduced sleep quality, and increased hypersensitivity (Mutluer, Doenyas, \& Aslan Genc, 2020). People with ASD also had difficulty understanding of the need for social distancing and staying at home, consistently using personal protective equipment (e.g., masks, gloves, etc.). Further, their caregivers did not have access to resources to educate their child with ASD about COVID-19 and ways to prevent infections. Finally, the study illustrated that increases in ASDrelated behavioral challenges were correlated with severity of anxiety in parents and caregivers. Similarly, another European study illustrated an exacerbation of pre-existing behavioral challenges in individuals with ASD, as well as parent reported challenges in managing free time and structured activities, during the COVID-19 pandemic (Colizzi et al., 2020). Children with ASD that did not receive services from schools experienced more intense behavioral problems.

Beyond the direct impact on behavior and physical health of individuals with ASD, the COVID-19 pandemic surfaced several related challenges, such as food insecurity and mental health problems among households (Jeste et al., 2020). As educational and public health institutions grapple with optimal protocols for school openings in the U.S., data on clinical experiences including prevalence of COVID-19 and hospitalization during the COVID19 pandemic for individuals with ASD are weak to nonexistent. It is postulated that since individuals with ASD have higher concentration of proinflammatory cytokines(Jyonouchi, 2013; Jyonouchi, Geng, Rose, Bennuri, \& Frye, 2019), seen in other chronic conditions that predispose individuals to COVID-19, the prevalence of COVID-19 infection in likely higher. The overlap in neuroinflammatory pathophysiology in ASD and COVID-19, could possibly exacerbate challenging behaviors and mental health problems (Lima, Barros, \& Aragao, 2020). A recent case series of sixteen patients with ASD with COVID-19 disease indicated that while most hospitalized individuals with ASD exhibited common symptoms of the infection, several had idiosyncratic manifestations contributing to challenges in diagnosis and treatment (Nollace et al., 2020). 
medRxiv preprint doi: https://doi.org/10.1101/2021.03.31.21254434; this version posted April 5, 2021. The copyright holder for this preprint

(which was not certified by peer review) is the author/funder, who has granted medRxiv a license to display the preprint in perpetuity.

It is made available under a CC-BY-NC-ND 4.0 International license .

Turk and colleagues, in their analysis utilizing the TriNetX COVID-19 Research Network Data, consisting of electronic medical records from 42 health systems in the U.S., illustrated that the case fatality rates for individuals with intellectual and developmental disabilities (IDD) was comparable to the general population. However, they also identified an age-related trend where the case fatality was higher among younger individuals with IDD than those without IDD, and it is likely due to higher proportion of comorbidities among young individuals with individuals with IDD (Turk, Landes, Formica, \& Goss, 2020). While it was not reported, it is likely that the study sample included many individuals with ASD grouped under the broad definition of IDD, as nearly $40 \%$ of individuals with ASD have cooccurring ID (Maenner, Shaw, Baio, \& al., 2020). To our knowledge, no prior study has examined the experiences of hospitalization, including the duration of hospital stay among individuals with ASD. Thus, the purpose of this analysis is to illustrate the impact of COVID-19 infection on health of individuals with ASD when compared to their peers with other chronic conditions.

Methods

Data source

Claims records from February 1, 2020 through September 30, 2020 from the FAIR Health National Private Insurance Claims (FH NPIC ${ }^{\odot}$ ) database were utilized for this analysis. The Centers for Medicare and Medicaid Services (CMS) Chronic Conditions Data Warehouse (CCW) definitions were applied to the diagnostic codes attached to the claims data. Additionally, diagnostic codes for each claim were examined retrospectively until October 1, 2017 to allow for capturing diagnosis of ASD and other listed CCW conditions from prior visits (for more information see: https://www2.ccwdata.org/web/guest/condition-categories). Professional and facility claims were examined to understand the prevalence of COVID-19 infection. A cohort of 35,898,076 patients who incurred a claim between February 1, 2020 and September 30, 2020 were analyzed. The following condition groups were created based on the diagnostic codes as dummy variables $(1=$ has this condition; $0=$ does not have this condition):

Autism Spectrum Disorders (ASD only); Autism Spectrum Disorders AND Intellectual Disabilities and Related

Conditions $(A S D+I D)$; Autism Spectrum Disorders AND Other Developmental Delays $(A S D+D D)$; Intellectual

Disabilities and Related Conditions; Attention-deficit/Hyperactivity disorder(ADHD), Conduct Disorders, and

Hyperkinetic Syndrome; Learning Disabilities; Other Developmental Delays; Hypertension; Chronic Kidney

Disease; Hyperlipidemia; Anemia; Diabetes; Ischemic Heart Disease; Heart Failure; Obesity; Rheumatoid 
medRxiv preprint doi: https://doi.org/10.1101/2021.03.31.21254434; this version posted April 5, 2021. The copyright holder for this preprint (which was not certified by peer review) is the author/funder, who has granted medRxiv a license to display the preprint in perpetuity.

It is made available under a CC-BY-NC-ND 4.0 International license .

Arthritis/ Osteoarthritis; Chronic Obstructive Pulmonary Disease; Atrial Fibrillation; Depressive Disorders; Anxiety Disorders; None of the Specified Conditions.

Specifically, claims with birth-related disorders (e.g., ASD, ID, DD) were assigned to their respective groups based on birth-related disorders to create mutually exclusive claim records. Claims that were likely to be adult-onset chronic conditions were grouped into their respective diagnostic category without being mutually exclusive as it was difficult to ascertain their primary diagnosis given the length of clinical history claims available for the analysis.

\section{Statistical analyses}

Any claim with a COVID-19 diagnosis resulting from hospitalization or a visit to doctor's office was recorded as a case of COVID-19. Descriptive analysis studied distribution in trends in hospitalization in the reported claims. Elevated length of stay was a categorical variable - longer than median length of stay for all claims and shorter than median length of stay. Two separate stepwise multiple logistic regression models were created to study the likelihood of hospitalization and experiencing elevated length of hospital stay. Each of the condition groups (e.g., ASD + ID, ASD + DD, ASD, etc.), coded as dummy variables, were entered along with gender (male; female) and age-groups ( $0-18$ years; $19-29$ years; $30-39$ years; $40-49$ years; $50-59$ years; $60-69$ years; 70 years and older) using the step-wise forward logistic regression with a significance level of 0.3 required to allow the variable into the model and a significance level of 0.35 required to allow the variable to stay into the model with each subsequent entry.

\section{Results}

Based on the analytical dataset, the overall prevalence of COVID-19 infection was estimated to be $2.04 \%$. Out of the total 144,147 individuals with ASD identified in the FAIR Health database who incurred a claim between February 2020 and September 2020, 1,300 individuals had a positive COVID-19 diagnosis resulting in an overall prevalence of $0.90 \%$. A greater proportion of individuals with ASD + ID, ASD + DD, and ASD only were males and belonged to young age-groups (i.e., 0 - 18 years, and $19-29$ years) compared with other condition groups. The estimated prevalence of COVID-19 infection was 2.01\% among individuals with ASD + ID (201 cases out of 9,991 individuals), $0.75 \%$ among individuals with ASD + DD (538 cases out of 71,999 individuals), and $0.90 \%$ among 
medRxiv preprint doi: https://doi.org/10.1101/2021.03.31.21254434; this version posted April 5, 2021. The copyright holder for this preprint (which was not certified by peer review) is the author/funder, who has granted medRxiv a license to display the preprint in perpetuity. It is made available under a CC-BY-NC-ND 4.0 International license .

individuals with ASD only (561 cases out of 62,165 individuals). The highest prevalence of COVID-19 was among individuals with heart failure without ASD or other developmental conditions (4.30\%). The overall mortality from COVID-19 for individuals in the analytical data set was $0.89 \%$. The proportion of deaths or mortality from COVID19 in infected individuals was $2.49 \%$ among individuals with ASD + ID, $0.37 \%$ among individuals with ASD + DD, and $0.89 \%$ for individuals with ASD only. Individuals with heart failure without ASD or other developmental conditions had the highest proportion of mortality from COVID-19 (10.5\%). Table 1 illustrates the proportion of prevalence and mortality for the condition groups. The unadjusted data (Figure 1) indicate larger proportions of outpatient doctor's office visits for individuals with ASD + ID, ASD + DD, and ASD only $(69.2 \%, 80.3 \%$, and $85.9 \%$ respectively). Further, as the proportion utilizing doctor's office declined, the proportion of claims with hospitalization increased.

The overall proportion of hospitalization for individuals with COVID-19 infection in the analytical data set was $12.70 \%$. Figure 2 illustrates the odds ratios for hospitalization for each of the condition groups based on the stepwise forward logistic regression model. After adjusting for age group and gender, individuals with ASD + ID were more than nine times likely to be hospitalized compared with those that did not have this condition $(\mathrm{OR}=9.3$; 95\% CI: 6.9 - 12.5). Similarly, individuals with ASD + DD were nearly six times more likely $(\mathrm{OR}=5.9 ; 95 \%$ CI: 4.7 - 7.3) and those with ASD only were nearly four times more likely to be hospitalized (OR $=3.6 ; 95 \% \mathrm{CI}: 2.9$ 4.6) compared to those that did not have this condition. The overall proportion of individuals with elevated length of of hospital stay (i.e., longer than median length) from COVID-19 infection was 5.58\%. Figure 3 illustrates the odds ratios for elevated length of hospital stay for each of the condition groups based on the stepwise forward logistic regression model. Individuals with ASD + ID were six times more likely to have elevated length of hospital stay compared to those that did not have this condition $(\mathrm{OR}=5.9 ; 95 \% \mathrm{CI}: 3.5-10.1)$. Individuals with ASD + DD were four times more likely ( $\mathrm{OR}=4.0 ; 95 \% \mathrm{CI}$ : $2.7-5.9)$, and those with ASD only were nearly three times more likely to have elevated length of hospital stay $(\mathrm{OR}=2.8 ; 95 \% \mathrm{CI}: 1.8-4.5)$ compared to those that did not have this condition.

Discussion 
medRxiv preprint doi: https://doi.org/10.1101/2021.03.31.21254434; this version posted April 5, 2021. The copyright holder for this preprint

(which was not certified by peer review) is the author/funder, who has granted medRxiv a license to display the preprint in perpetuity.

It is made available under a CC-BY-NC-ND 4.0 International license .

This is a first study to illustrate a higher likelihood of hospitalization and elevated length of hospital stay in COVID-19 for individuals with ASD and other comorbidities. While a lower proportion of individuals with ASD acquired COVID-19 infection compared to other condition groups, they were significantly more likely to be hospitalized for COVID-19 and have longer length of stay in the hospital. Contrastingly, individuals with other chronic conditions had higher prevalence of COVID-19 infections (e.g., Heart Failure, Obesity, Diabetes) had lower adjusted odds of hospitalization and elevated length of hospital stay. A lower overall prevalence of COVID-19 in ASD is likely driven by underlying demographic patterns. A closer examination of the demographic distribution indicates that more than $90 \%$ of individuals with ASD were in the younger age range (i.e., less than 30 years old), of which nearly $70 \%$ belonged to $0-18$-year-old group. As a result, most individuals with ASD in the data are likely living with their families during pandemic and as a result are less likely to acquire COVID-19 infection than individuals in other settings such as congregate living environments. A substantial amount of reporting of higher morbidity and mortality in COVID-19 among individuals with disabilities, especially for those with intellectual and developmental disabilities have been associated with their living situation in congregate care settings (Landes, Turk, Formica, McDonald, \& Stevens, 2020).

Once individuals with ASD acquire COVID-19 infection, the regression models indicate that they have a higher likelihood of hospitalization and elevated length hospital stay. While Cunningham and colleagues (2020) described a similar pattern of lower COVID-19 prevalence and higher morbidity among young individuals using electronic medical records data, the quantitative differences in the likelihood of hospitalization and duration of stay for individuals with ASD is concerning and requires attention (Cunningham et al., 2020). It is known that individuals with ASD, in general, have higher medical needs resulting from cooccurring mental health and other conditions such as epilepsy, digestive disorders, etc. (Karpur, Lello, Frazier, Dixon, \& Shih, 2018; Shea et al., 2018) It is possible that the COVID-19 infection, irrespective of severity, precipitates behavior health challenges leading to hospitalization and longer duration of stay (Righi et al., 2017). Further, Several immunological theories, including the more recent preposition of abnormal melatonin production among individuals ASD, might contributed to the increased severity of COVID-19 infection (Brown et al., 2021).

The findings of increased morbidity in COVID-19 are relevant from the perspective of increasing discussion on prioritization of populations for COVID-19 vaccines. Only a handful of states have considered 
medRxiv preprint doi: https://doi.org/10.1101/2021.03.31.21254434; this version posted April 5, 2021. The copyright holder for this preprint (which was not certified by peer review) is the author/funder, who has granted medRxiv a license to display the preprint in perpetuity.

It is made available under a CC-BY-NC-ND 4.0 International license .

prioritizing individuals with intellectual disabilities (see: https://www.kff.org/policy-watch/the-next-phase-ofvaccine-distribution-high-risk-medical-conditions/) and this does not include all individuals with ASD. However, given the challenges in consistently implementing social distancing practices, and use of PPEs among individuals with ASD it would be useful to also include them as one of the high-risk populations for immunizations.

These analyses are limited by a few factors. Firstly, the FH NPIC ${ }^{\circ}$ data are limited to just private health claims data, while many people with ASD are on public insurance like Medicaid. Medicaid funds both healthcare and long-term services and supports such as congregate or community-based housing for people with ASD or other developmental disabilities. Future studies should explore hospitalization and length of stay because of COVID-19 for people with ASD who have Medicaid. Secondly, the findings are based on claims data that trigger a record upon receipt of services and the record for this study extends only to September 2020. It is possible that the prevalence of COVID-19 infection is much higher than is reported here in the analysis and it certainly increased substantially, as infections increased in late fall/early winter. An additional limitation is that condition identification was based on the ICD-10 diagnostic codes that may miss some individuals. Further, a substantial proportion of private claims data do not report on race/ethnicity, making it difficult to examine disparities in experiences (Ng, Ye, Ward, Haffer, \& Scholle, 2017). Factors indicative of social and economic vulnerability, including living situation, would likely present more nuanced and policy-relevant findings. Future studies that employ natural language processing or medical record review to identify COVID-19, people with ASD, and other important factors related to hospitalization and length of stay would be useful for extending the present work and further characterizing the impact of COVID-19 on the ASD population. 
medRxiv preprint doi: https://doi.org/10.1101/2021.03.31.21254434; this version posted April 5, 2021. The copyright holder for this preprint

(which was not certified by peer review) is the author/funder, who has granted medRxiv a license to display the preprint in perpetuity.

It is made available under a CC-BY-NC-ND 4.0 International license .

\section{References}

Brown, G. M., Karthikeyan, R., Pandi-Perumal, S. R., \& Cardinali, D. P. (2021). Autism spectrum disorder patients may be susceptible to COVID-19 disease due to deficiency in melatonin. Medical Hypotheses, 110544. doi:10.1016/j.mehy.2021.110544

Colizzi, M., Sironi, E., Antonini, F., Ciceri, M. L., Bovo, C., \& Zoccante, L. (2020). Psychosocial and Behavioral Impact of COVID-19 in Autism Spectrum Disorder: An Online Parent Survey. Brain Sci, 10(6). doi:10.3390/brainsci10060341

Cunningham, J. W., Vaduganathan, M., Claggett, B. L., Jering, K. S., Bhatt, A. S., Rosenthal, N., \& Solomon, S. D. (2020). Clinical Outcomes in Young US Adults Hospitalized With COVID-19. JAMA Internal Medicine. doi:10.1001/jamainternmed.2020.5313

Jeste, S., Hyde, C., Distefano, C., Halladay, A., Ray, S., Porath, M., . . Thurm, A. (2020). Changes in access to educational and healthcare services for individuals with intellectual and developmental disabilities during COVID-19 restrictions. Journal of Intellectual Disability Research, 64(11), 825-833.

\section{doi:https://doi.org/10.1111/jir.12776}

Jyonouchi, H. (2013). Immunological Abnormalities in Autism Spectrum Disorders. Advances in Neuroimmune Biology, 4, 141-159. doi:10.3233/NIB-130061

Jyonouchi, H., Geng, L., Rose, S., Bennuri, S. C., \& Frye, R. E. (2019). Variations in Mitochondrial Respiration Differ in IL-1ß/IL-10 Ratio Based Subgroups in Autism Spectrum Disorders. Frontiers in Psychiatry, 10(71). doi:10.3389/fpsyt.2019.00071

Karpur, A., Lello, A., Frazier, T., Dixon, P. J., \& Shih, A. J. (2018). Health Disparities among Children with Autism Spectrum Disorders: Analysis of the National Survey of Children's Health 2016. J Autism Dev Disord. doi:10.1007/s10803-018-3862-9

Landes, S. D., Turk, M. A., Formica, M. K., McDonald, K. E., \& Stevens, J. D. (2020). COVID-19 outcomes among people with intellectual and developmental disability living in residential group homes in New York State. Disability and Health Journal, 13(4), 100969-100969.

Lima, M. E. S., Barros, L. C. M., \& Aragao, G. F. (2020). Could autism spectrum disorders be a risk factor for COVID-19? Med Hypotheses, 144, 109899. doi:10.1016/j.mehy.2020.109899 
medRxiv preprint doi: https://doi.org/10.1101/2021.03.31.21254434; this version posted April 5, 2021. The copyright holder for this preprint

(which was not certified by peer review) is the author/funder, who has granted medRxiv a license to display the preprint in perpetuity.

It is made available under a CC-BY-NC-ND 4.0 International license .

Maenner, M., Shaw, K. A., Baio, J., \& al., e. (2020). Prevalence of autism spectrum disorders among children aged 8 years - Autism and Developmental Disabilities Monitoring Network, 11 sites, United States, 2016. Morbidity and Mortality Weekly Report, 69(4), 1 - 12.

Mutluer, T., Doenyas, C., \& Aslan Genc, H. (2020). Behavioral Implications of the Covid-19 Process for Autism Spectrum Disorder, and Individuals' Comprehension of and Reactions to the Pandemic Conditions. Front Psychiatry, 11, 561882. doi:10.3389/fpsyt.2020.561882

Ng, J. H., Ye, F., Ward, L. M., Haffer, S. C., \& Scholle, S. H. (2017). Data On Race, Ethnicity, And Language Largely Incomplete For Managed Care Plan Members. Health Aff (Millwood), 36(3), 548-552. doi:10.1377/hlthaff.2016.1044

Nollace, L., Cravero, C., Abbou, A., Mazda-Walter, B., Bleibtreu, A., Pereirra, N., . . Giannitelli, M. (2020). Autism and COVID-19: A Case Series in a Neurodevelopmental Unit. J Clin Med, 9(9). doi: $10.3390 /$ jcm 9092937

Righi, G., Benevides, J., Mazefsky, C., Siegel, M., Sheinkopf, S., \& Morrow, E. (2017). Predictors of Inpatient Psychiatric Hospitalization for Children and Adolescents with Autism Spectrum Disorder. Journal of Autism and Developmental Disorders, 48(11), 3647-3657.

Shea, L. L., Xie, M., Turcotte, P., Marcus, S., Field, R., Newschaffer, C., \& Mandell, D. (2018). Brief Report: Service Use and Associated Expenditures Among Adolescents with Autism Spectrum Disorder Transitioning to Adulthood. J Autism Dev Disord. doi:10.1007/s10803-018-3563-4

Turk, M. A., Landes, S. D., Formica, M. K., \& Goss, K. D. (2020). Intellectual and developmental disability and COVID-19 case-fatality trends: TriNetX analysis. Disability and Health Journal, 13(3), 100942-100942. 
medRxiv preprint doi: https://doi.org/10.1101/2021.03.31.21254434; this version posted April 5, 2021. The copyright holder for this preprint (which was not certified by peer review) is the author/funder, who has granted medRxiv a license to display the preprint in perpetuity. It is made available under a CC-BY-NC-ND 4.0 International license .

\section{Footnotes}

1. Research for this article is based upon healthcare claims data compiled and maintained by FAIR Health, Inc. The authors are solely responsible for the conclusions reflected in this article. FAIR Health, Inc. is not responsible for the any of the opinions expressed in this article. 
medRxiv preprint doi: https://doi.org/10.1101/2021.03.31.21254434; this version posted April 5, 2021. The copyright holder for this preprint (which was not certified by peer review) is the author/funder, who has granted medRxiv a license to display the preprint in perpetuity.

It is made available under a CC-BY-NC-ND 4.0 International license .

Table 1. Prevalence of COVID-19 infection and mortality in condition groups

\begin{tabular}{|l|l|l|}
\hline Condition Groups & $\begin{array}{l}\text { Prevalence } \\
\text { Proportion }\end{array}$ & $\begin{array}{l}\text { Mortality } \\
\text { Proportion }\end{array}$ \\
\hline Autism Spectrum Disorders AND Other Developmental Delays & $0.75 \%$ & $0.37 \%$ \\
\hline Learning Disabilities & $0.85 \%$ & $1.21 \%$ \\
\hline Autism Spectrum Disorders & $0.90 \%$ & $0.89 \%$ \\
\hline Other Developmental Delays & $0.95 \%$ & $0.57 \%$ \\
\hline None of the Specified Conditions & $1.57 \%$ & $0.02 \%$ \\
\hline ADHD, Conduct Disorders, and Hyperkinetic Syndrome & $1.94 \%$ & $0.48 \%$ \\
\hline $\begin{array}{l}\text { Autism Spectrum Disorders AND Intellectual Disabilities and } \\
\text { Related Conditions }\end{array}$ & $2.01 \%$ & $2.49 \%$ \\
\hline Intellectual Disabilities and Related Conditions & $2.21 \%$ & $5.44 \%$ \\
\hline Depressive Disorders & $2.51 \%$ & $2.02 \%$ \\
\hline Anxiety Disorders & $2.70 \%$ & $1.45 \%$ \\
\hline Rheumatoid Arthritis/ Osteoarthritis & $2.76 \%$ & $2.45 \%$ \\
\hline Hyperlipidemia & $2.92 \%$ & $2.00 \%$ \\
\hline Hypertension & $2.98 \%$ & $2.77 \%$ \\
\hline Atrial Fibrillation & $3.19 \%$ & $8.87 \%$ \\
\hline Ischemic Heart Disease & $3.35 \%$ & $6.49 \%$ \\
\hline Obesity & $3.51 \%$ & $1.85 \%$ \\
\hline Diabetes & $3.60 \%$ & $3.19 \%$ \\
\hline Chronic Obstructive Pulmonary Disease & $3.74 \%$ & $5.23 \%$ \\
\hline Chronic Kidney Disease & $3.81 \%$ & $7.17 \%$ \\
\hline Anemia & $4.11 \%$ & $3.47 \%$ \\
\hline Heart Failure & $4.30 \%$ & $10.50 \%$ \\
\hline
\end{tabular}

Note: Data table is sorted in the descending order of the prevalence proportion. 
medRxiv preprint doi: https://doi.org/10.1101/2021.03.31.21254434; this version posted April 5, 2021. The copyright holder for this preprint (which was not certified by peer review) is the author/funder, who has granted medRxiv a license to display the preprint in perpetuity. It is made available under a CC-BY-NC-ND 4.0 International license .

Figure 1. Frequency of outpatient visits and hospitalizations in COVID-19 for condition groups

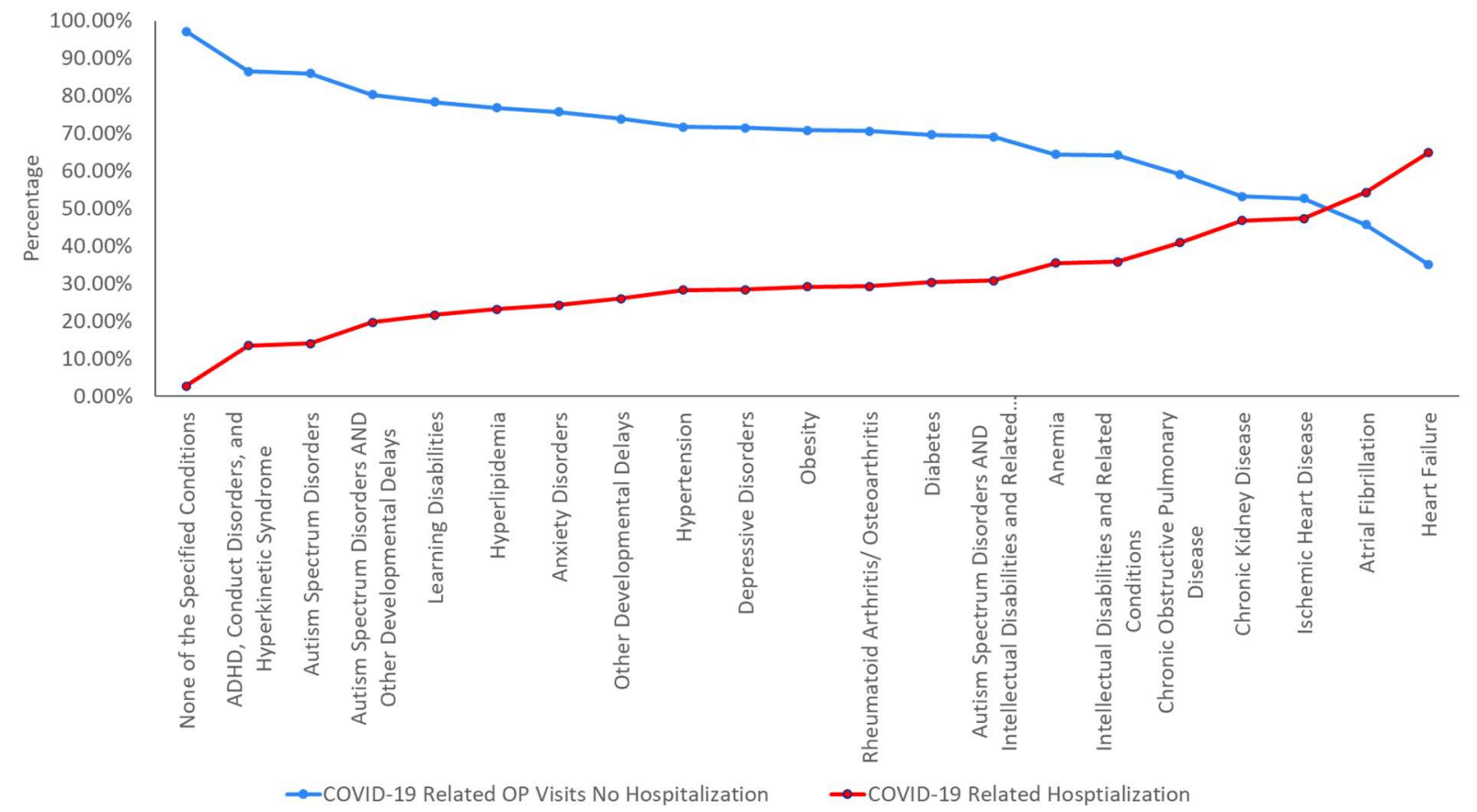


medRxiv preprint doi: https://doi.org/10.1101/2021.03.31.21254434; this version posted April 5, 2021. The copyright holder for this preprint (which was not certified by peer review) is the author/funder, who has granted medRxiv a license to display the preprint in perpetuity. It is made available under a CC-BY-NC-ND 4.0 International license .

Figure 2. Likelihood of hospitalization in COVID-19 infection across the condition groups

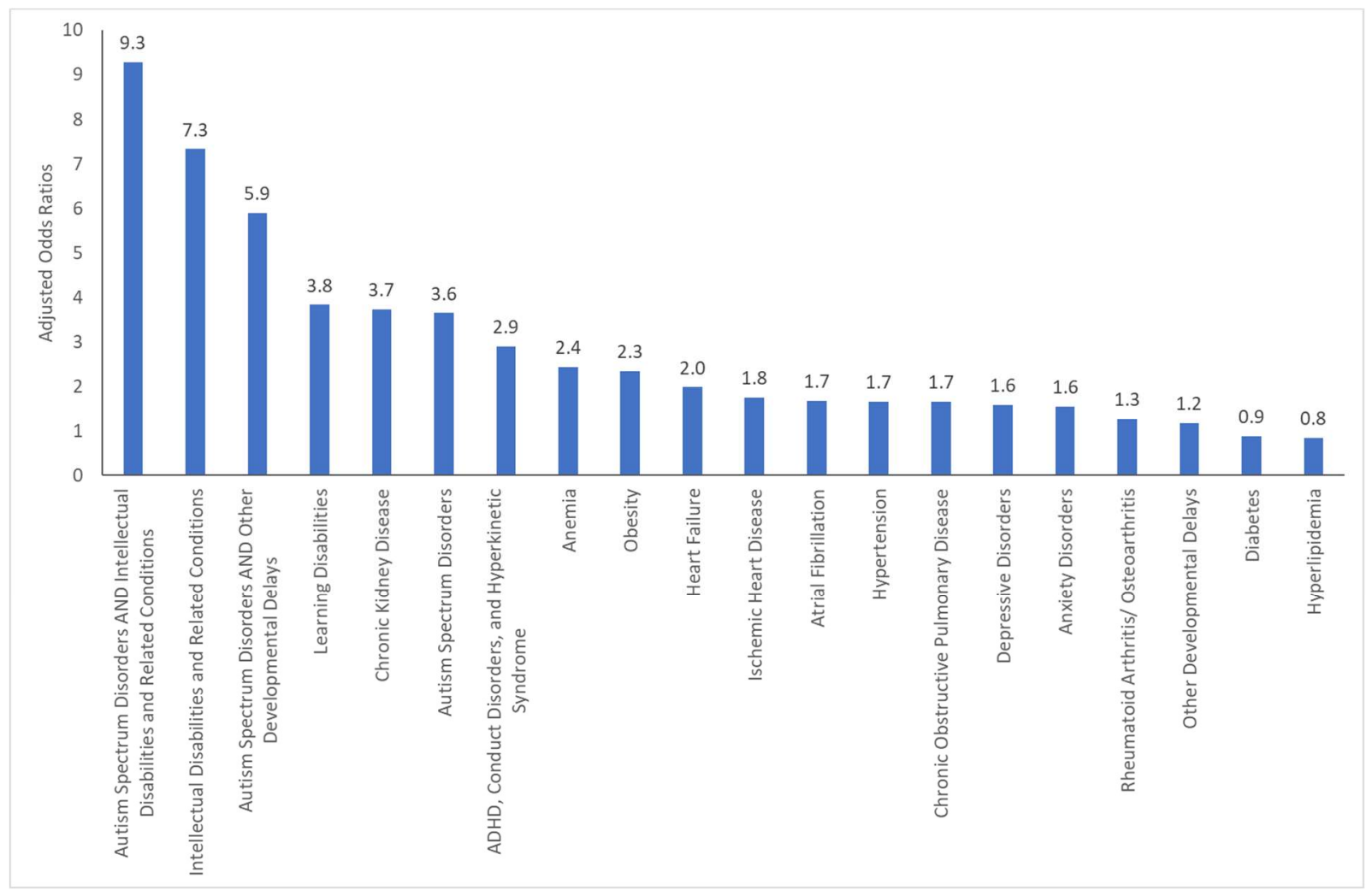


medRxiv preprint doi: https://doi.org/10.1101/2021.03.31.21254434; this version posted April 5, 2021. The copyright holder for this preprint (which was not certified by peer review) is the author/funder, who has granted medRxiv a license to display the preprint in perpetuity. It is made available under a CC-BY-NC-ND 4.0 International license .

Figure 3. Likelihood of higher than median length of stay in hospital from COVID-19 infection

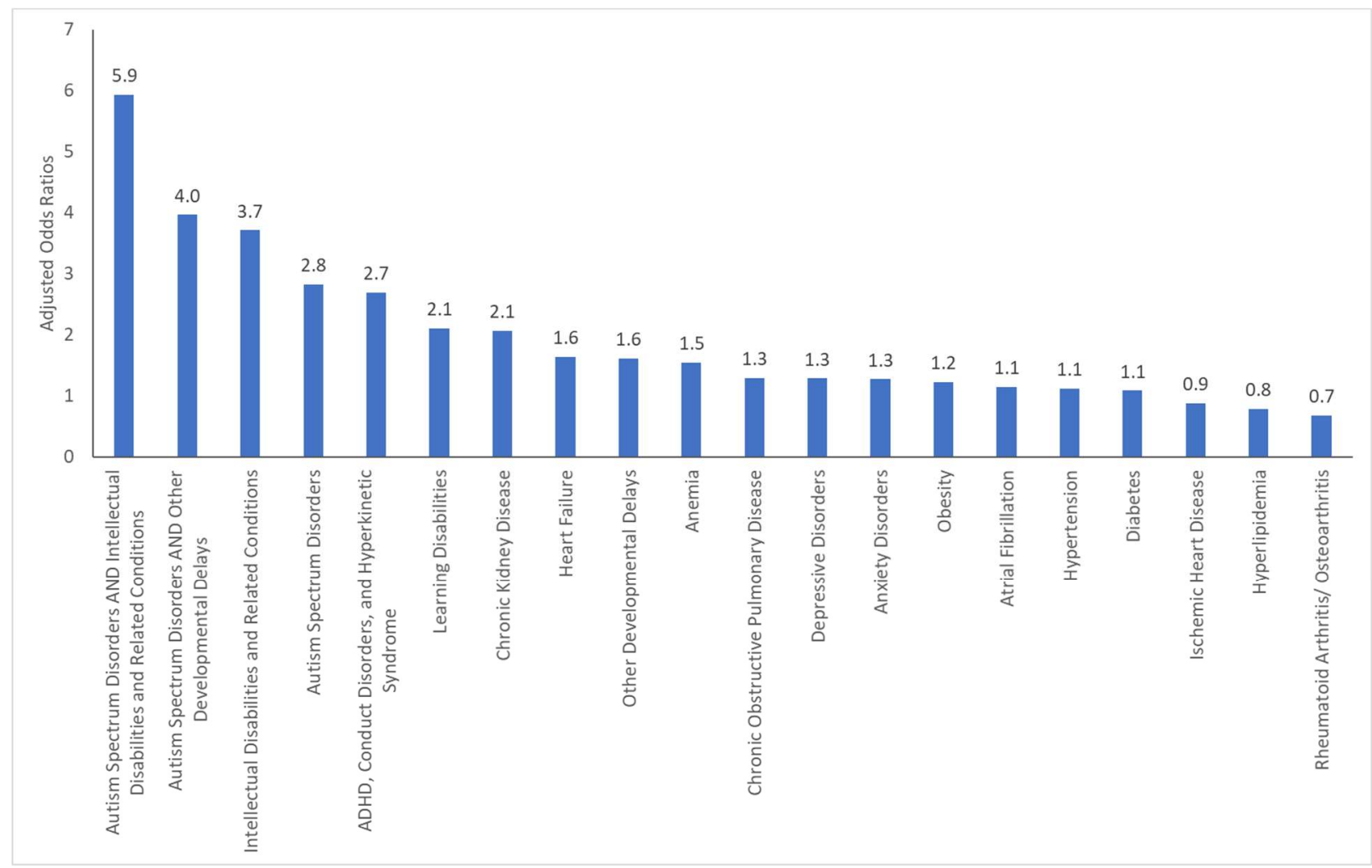


Supplementary Materials

Table 1. Results from stepwise forward logistic regression model for hospitalization in COVID-19

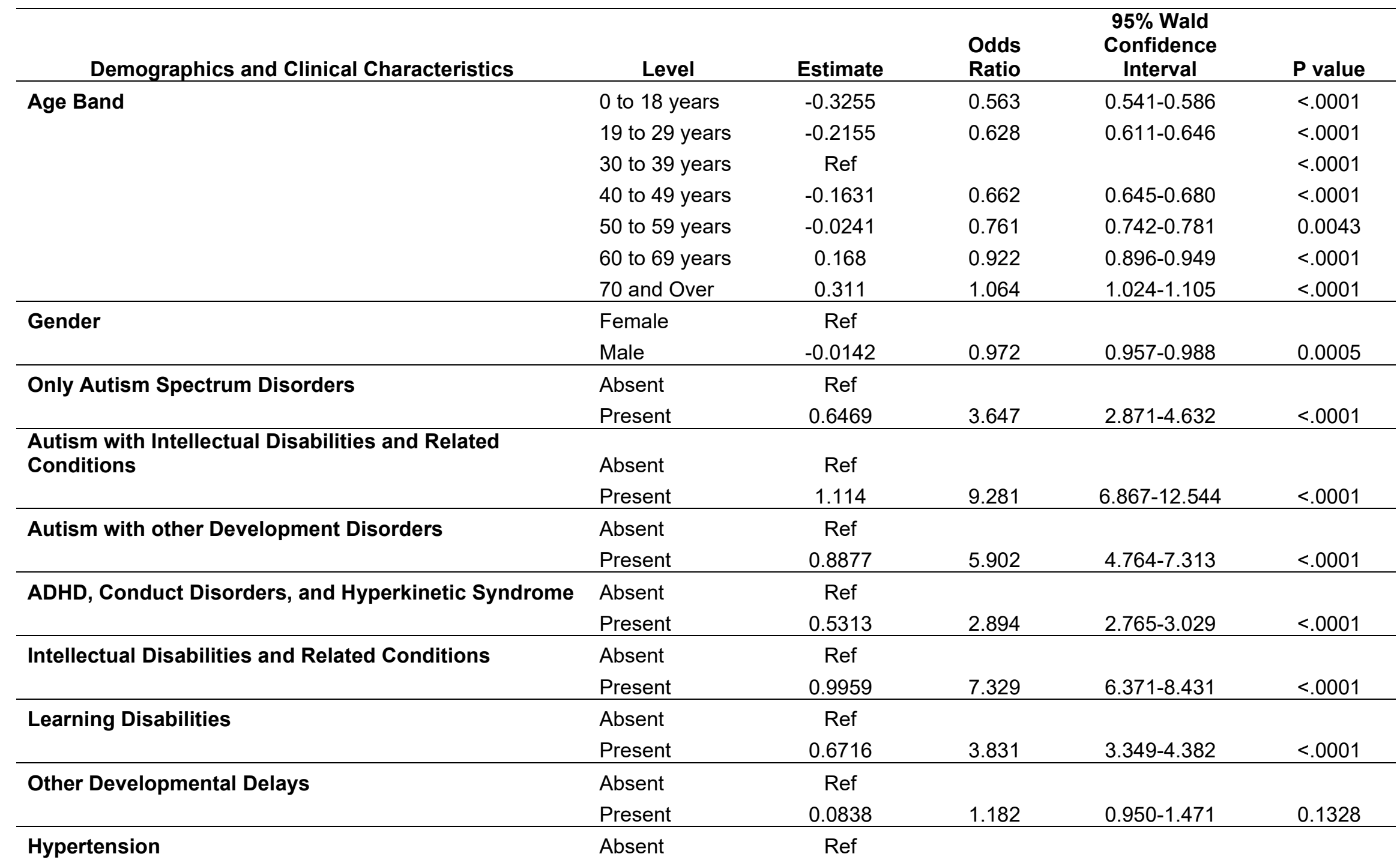




\begin{tabular}{|c|c|c|c|c|c|}
\hline & Present & 0.2535 & 1.66 & $1.627-1.695$ & $<.0001$ \\
\hline Chronic Kidney Disease & Absent & Ref & & & \\
\hline Hyperlipidemia & Absent & Ref & & & \\
\hline \multirow[t]{2}{*}{ Anemia } & Absent & Ref & & & \\
\hline & Present & 0.4453 & 2.436 & $2.389-2.485$ & $<.0001$ \\
\hline \multirow[t]{2}{*}{ Ischemic Heart Disease } & Absent & Ref & & & \\
\hline & Present & 0.2812 & 1.755 & $1.704-1.807$ & $<.0001$ \\
\hline \multirow[t]{2}{*}{ Heart Failure } & Absent & Ref & & & \\
\hline & Present & 0.3416 & 1.98 & $1.900-2.064$ & $<.0001$ \\
\hline Obesity & Absent & Ref & & & \\
\hline $\begin{array}{l}\text { Chronic Obstructive Pulmonary Disease and } \\
\text { Bronchitis }\end{array}$ & Present & 0.252 & 1.655 & 1.603-1.709 & $<.0001$ \\
\hline \multirow[t]{2}{*}{ Atrial Fibrillation } & Absent & Ref & & & \\
\hline & Present & 0.26 & 1.682 & $1.614-1.753$ & $<.0001$ \\
\hline \multirow[t]{2}{*}{ Depression } & Absent & Ref & & & \\
\hline & Present & 0.2279 & 1.577 & $1.539-1.617$ & $<.0001$ \\
\hline \multirow[t]{2}{*}{ Anxiety Disorders } & Absent & Ref & & & \\
\hline & Present & 0.2204 & 1.554 & $1.520-1.589$ & $<.0001$ \\
\hline
\end{tabular}

Note: Data source FAIR Health National Private Insurance Claims (FH NPIC $\left.{ }^{\odot}\right)$. C-statistic $=0.805$. 
Table 2. Results from stepwise forward logistic regression model for mean length of stay in hospital in COVID-19

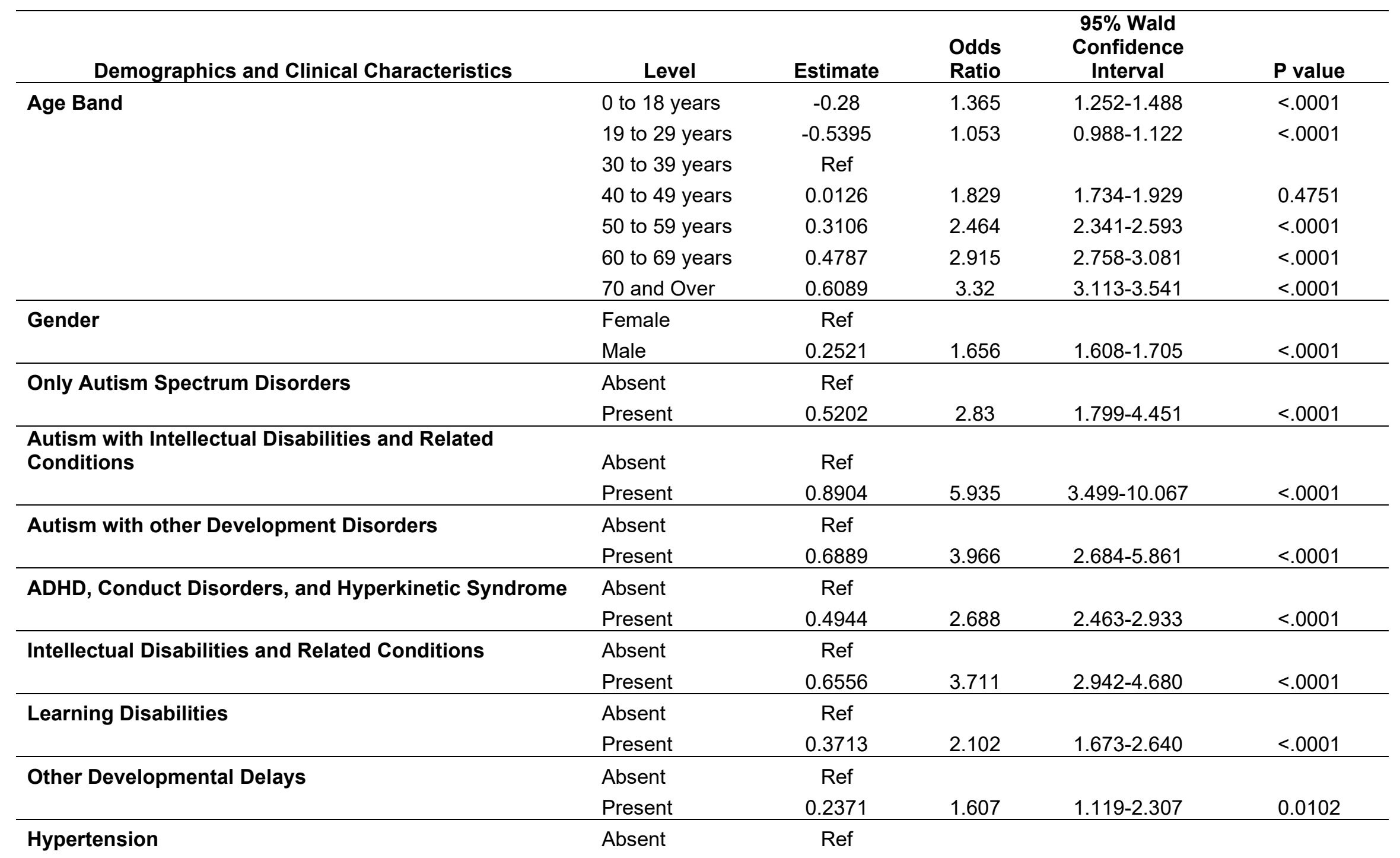




\begin{tabular}{|c|c|c|c|c|c|}
\hline & Present & 0.0547 & 1.116 & $1.075-1.157$ & $<.0001$ \\
\hline \multirow[t]{2}{*}{ Chronic Kidney Disease } & Absent & Ref & & & \\
\hline & Present & 0.3632 & 2.068 & $1.997-2.141$ & $<.0001$ \\
\hline \multirow[t]{2}{*}{ Hyperlipidemia } & Absent & Ref & & & \\
\hline & Present & -0.1252 & 0.779 & $0.752-0.806$ & $<.0001$ \\
\hline \multirow[t]{2}{*}{ Anemia } & Absent & Ref & & & \\
\hline & Present & 0.2186 & 1.549 & $1.501-1.598$ & $<.0001$ \\
\hline \multirow[t]{2}{*}{ Diabetes } & Absent & Ref & & & \\
\hline & Present & 0.0404 & 1.084 & $1.046-1.124$ & $<.0001$ \\
\hline \multirow[t]{2}{*}{ Ischemic Heart Disease } & Absent & Ref & & & \\
\hline & Present & -0.0625 & 0.883 & $0.846-0.921$ & $<.0001$ \\
\hline \multirow[t]{2}{*}{ Heart Failure } & Absent & Ref & & & \\
\hline & Present & 0.2452 & 1.633 & $1.551-1.720$ & $<.0001$ \\
\hline \multirow[t]{2}{*}{ Obesity } & Absent & Ref & & & \\
\hline & Present & 0.0994 & 1.22 & 1.183-1.258 & $<.0001$ \\
\hline \multirow[t]{2}{*}{ Rheumatoid Arthritis / Osteoarthritis } & Absent & Ref & & & \\
\hline & Present & -0.1953 & 0.677 & $0.653-0.702$ & $<.0001$ \\
\hline \multirow[t]{2}{*}{ Chronic Obstructive Pulmonary Disease and Bronchitis } & Absent & Ref & & & \\
\hline & Present & 0.1293 & 1.295 & $1.237-1.355$ & $<.0001$ \\
\hline \multirow[t]{2}{*}{ Atrial Fibrillation } & Absent & Ref & & & \\
\hline & Present & 0.0696 & 1.149 & $1.090-1.212$ & $<.0001$ \\
\hline \multirow[t]{2}{*}{ Depression } & Absent & Ref & & & \\
\hline & Present & 0.1255 & 1.285 & $1.235-1.338$ & $<.0001$ \\
\hline \multirow[t]{2}{*}{ Anxiety Disorders } & Absent & Ref & & & \\
\hline & Present & 0.1198 & 1.271 & $1.224-1.319$ & $<.0001$ \\
\hline
\end{tabular}

Note: Data source FAIR Health National Private Insurance Claims $\left(\right.$ FH NPIC $\left.{ }^{\odot}\right)$. C-statistic $=0.724$. 